\title{
Pemanfaatan Rimpang Kunyit (Curcuma domestica Val) Dalam Upaya Mempertahankan Mutu Ikan Layang (Decapterus sp)
}

\section{Erling Pasaraenga*, Jemmy Abidjulua, Max R. J. Runtuwenea}

aJurusan Kimia, FMIPA, Unsrat, Manado

\begin{tabular}{l}
\hline K A T A K U N C I \\
\hline Ikan layang \\
Decapterus sp. \\
Kunyit \\
Total Volatile Base (TVB)
\end{tabular}

\begin{tabular}{l}
\hline K E Y W O R D S \\
\hline Scad \\
Decapterus sp. \\
Turmeric \\
Total Volatile Base (TVB)
\end{tabular}

AVAILABLE ONLINE 20 Juni 2013

\begin{abstract}
A B S T R A K
Kunyit mengandung kurkumin dan minyak atsiri yang telah diketahui memiliki aktivitas antibakteri. Penelitian ini bertujuan untuk mengetahui pengaruh penambahan kunyit (Curcuma domestica Val) terhadap mutu ikan layang (Decapterus sp), melalui uji Total Volatile Base (TVB). Hasil perhitungan total nilai TVB untuk sampel ikan layang tanpa penambahan kunyit pada jam ke-6 adalah 92,4 mg N/100 g, untuk sampel ikan layang dengan penambahan kunyit $100 \mathrm{~g}$ adalah 37,8 mg N/100 g dan untuk sampel ikan dengan penambahan kunyit 200 g adalah 28,56 mg N/100 g. Hal ini menunjukan bahwa pemberian kunyit pada ikan layang mampu menghambat pertumbuhan bakteri sehingga dapat mempertahankan mutu ikan layang. Penambahan kunyit 200 g mempunyai nilai TVB paling rendah, artinya mempunyai daya penghambat yang lebih baik dari pada penambahan $100 \mathrm{~g}$ kunyit pada ikan layang.
\end{abstract}

\begin{tabular}{l}
\hline A B S T R A C T \\
Turmeric contains curcumin and essential oil having antibacterial \\
activity. This study was aimed to investigate the effect of turmeric \\
(Curcuma domestica Val) on the quality of scad (Decapterus sp) using \\
Total Volatile Base (TVB) test. The results showed that the TVB at hour 6 \\
for scad samples without the addition of turmeric was $92.4 \mathrm{mg} \mathrm{N} / 100 \mathrm{~g}$, \\
that for fish samples with the addition of $100 \mathrm{~g}$ turmeric was $37.8 \mathrm{mg}$ \\
$\mathrm{N} / 100 \mathrm{~g}$, and that for fish samples with the addition of $200 \mathrm{~g}$ turmeric was \\
$28.56 \mathrm{mg} \mathrm{N} / 100 \mathrm{~g}$. This shows that administration of turmeric on scad \\
could inhibit the growth of bacteria and maintain the quality of Decapterus \\
sp. The addition of turmeric $200 \mathrm{~g}$ resulted in highest antibacterial activity \\
reflected in the lowest value of TVB.
\end{tabular}

\begin{abstract}
1. Pendahuluan
Indonesia sebagai negara kepulauan yang terletak di daerah khatulistiwa terdiri atas 17.508 pulau besar dan kecil, dengan panjang garis pantai kurang lebih $81.000 \mathrm{~km}$. Luas laut Indonesia mencapai 3,9 juta $\mathrm{km}^{2}$ dan ZEE 2,7 juta $\mathrm{km}^{2}$ dimana $81,20 \%$ total luas wilayahnya berupa laut. Kondisi ini menyebabkan Indonesia menjadi negara bahari yang memiliki sumber daya perairan yang melimpah. Salah satu sumber daya perairan adalah ikan layang (Begen, 2002).
\end{abstract}

Ikan layang (Decapterus sp) merupakan salah satu bahan pangan yang memiliki kandungan zat gizi tinggi yang dibutuhkan tubuh manusia. Menurut Berhimpon (1982), bahan pangan ini mengandung protein, kadar air dan asam-asam amino esensial yang lengkap dan dalam jumlah yang cukup. Ikan ini cukup melimpah dan rasanya enak sehingga banyak digemari. Akan tetapi Ikan ini juga merupakan produk yang cepat menjadi busuk yang menyebabkan mutu ikan mengalami kemunduran. Faktor utama yang berperan dalam pembusukan adalah Ikan Layang mempunyai tekstur yang lunak, kandungan kadar air yang tinggi, kadar protein yang

*Corresponding author: Jurusan Kimia FMIPA UNSRAT, Jl. Kampus Unsrat, Manado, Indonesia 95115; Email address: er.ling38@yahoo.co.id 
cukup tinggi sehingga terjadi proses degradasi protein serta tingginya jumlah bakteri yang terkandung di dalam perut ikan (Harisna, 2010). Oleh karena itu diperlukan suatu cara untuk mempertahankan mutu ikan. Salah satunya adalah dengan cara pengawetan. Pengawetan yang biasa dilakukan cukup beragam mulai penggunaan pendingin, radiasi, bahkan sampai menggunakan formalin dan bahan aditif

Menurut Harisna (2010), rempah-rempah dan bumbu asli Indonesia ternyata banyak mengandung senyawa anti bakteri, Salah satunya adalah kunyit (Curcuma domestica Val) yang terbukti mengandung bahan-bahan yang dapat berfungsi sebagai antibakteri. Rimpang kunyit mengandung senyawa kurkumin yang bersifat sebagai antibakteri (Rahman, 2009). Senyawa lain yang juga bersifat sebagai antibakteri yang terdapat dalam rimpang kunyit adalah minyak atsiri (Marwati, 1996).

Penilitian ini bertujuan untuk: (1) mengetahui pengaruh penambahan kunyit terhadap mutu ikan layang, dan (2) mengetahui pengaruh penambahan kunyit 100 g dan 200 g kunyit terhadap mutu ikan layang melalui metode TVB.

\section{Bahan dan Metode}

Penelitian ini dilaksanakan di Laboratorium Kimia dan Mikrobiologi Fakultas Perikanan Unsrat. Alat utama yang digunakan adalah cawan Conway dan peralatan titrasi. sedangkan bahan-bahan yang digunakan adalah ikan layang, kunyit, air laut, Kalium karbonat $\left(\mathrm{K}_{2} \mathrm{CO}_{3}\right)$, trikloro acid (TCA) $7 \%$, Asam borat $\left(\mathrm{H}_{3} \mathrm{BO}_{3}\right)$, asam klorida $(\mathrm{HCl})$, larutan indikator (yang dibuat dengan perbandingan metil red $0,066 \%$ dan bromocresol green 0, 033\% yang dilarutkan dalam etanol 90\%, vaselin, akuades.

\subsection{Persiapan Sampel Ikan dan Aplikasi Kunyit}

Sampel berupa ikan layang, di masukkan ke dalam wadah plastik yang berisi 100 g kunyit dan $1000 \mathrm{~mL}$ air laut, hal yang sama juga di lakukan untuk sampel dengan penambahan kunyit $200 \mathrm{~g}$ dan $1000 \mathrm{~mL}$ air laut, untuk kontrol sampel tidak diberi kunyit dan air laut. Daging ikan diambil lalu diuji Total Volatile Base (TVB) pada selang waktu 0, 1, 3, dan 6 jam.

\subsection{Penentuan TVB}

Penentuan Total Volatile Base (TVB) menggunakan metode Conway (Suwetja, 1993). Sampel yang telah dihaluskan ditimbang sebanyak 5 g kemudian ditambahkan $10 \mathrm{~mL}$ larutan TCA 7\% dan selanjutnya diaduk dengan batang pengaduk magnetik sampai homogen. Larutan disaring dengan menggunakan kertas saring sehingga filtrat yang di peroleh berwarna jernih. Selanjutnya dipipet $1 \mathrm{~mL} \mathrm{H}_{3} \mathrm{BO}_{3}$ dan beberapa tetes larutan indikator dimasukan ke dalam inner chamber cawan Conway (bagian dalam cawan). Dengan memakai pipet lainnya filtrat contoh sebanyak $1 \mathrm{~mL}$ dimasukan ke dalam outer chamber cawan Conway (bagian luar) kemudian ditambahkan1 $\mathrm{mL}$ larutan $\mathrm{K}_{2} \mathrm{CO}_{3}$ ke dalam outer chamber dengan posisi cawan Conway hampir menutup, setelah itu cawan Conway di tutup rapat. Sebelumnya bagian pingir cawan Conway dan penutupnya diolesi vaselin sehingga diperoleh penutupan yang rapat.

Sementara itu blangko dikerjakan, filtrat sampel diganti dengan larutan TCA $7 \%$ sebanyak 1 $\mathrm{mL}$ dan dikerjakan seperti prosedur di atas. Cawan Conway yang telah ditutup rapat digoyangkan perlahan-lahan selama 1 menit agar larutan ekstraksi daging ikan dan $\mathrm{K}_{2} \mathrm{CO}_{3}$ dapat tercampur, kemudian disimpan pada suhu $37^{\circ} \mathrm{C}$ selama 2 jam.

Setelah selesai diinkubasi, larutan $\mathrm{H}_{3} \mathrm{BO}_{3}$ di dalam inner chamber cawan Conway blangko dititrasi dengan $0,02 \mathrm{~N} \mathrm{HCl}$, hingga larutan berwarna merah muda (pink). Selanjutnya berturutturut larutan $\mathrm{H}_{3} \mathrm{BO}_{3}$ di dalam inner chamber cawan Conway sampel dititrasi dengan 0,02 $\mathrm{N} \mathrm{HCl}$ sampai larutan berwarna merah muda seperti blangko.

Perhitungan kadar TVB dalam 100 g daging ikan dapat di tentukan dengan menggunakan rumus:

$$
\begin{aligned}
& \text { TVB (mg N/100 g daging) }= \\
& (x-a) \times 0,28 \times \text { pengenceran }
\end{aligned}
$$

dengan $x$ adalah jumlah $\mathrm{mL}$ asam klorida yang dipakai mentiter larutan sampel, a adalah jumlah $\mathrm{mL}$ asam klorida yang dipakai mentiter blangko, 0,28 adalah jumlah amonium nitrogen yang setara dengan $1 \mathrm{~mL}$ 0,02 N larutan asam klorida.

3. Hasil dan Pembahasan

\subsection{Sampel Ikan Layang Tanpa Penambahan Kunyit}

Nilai TVB ikan layang tanpa penambahan kunyit dapat dilihat pada Gambar 1.

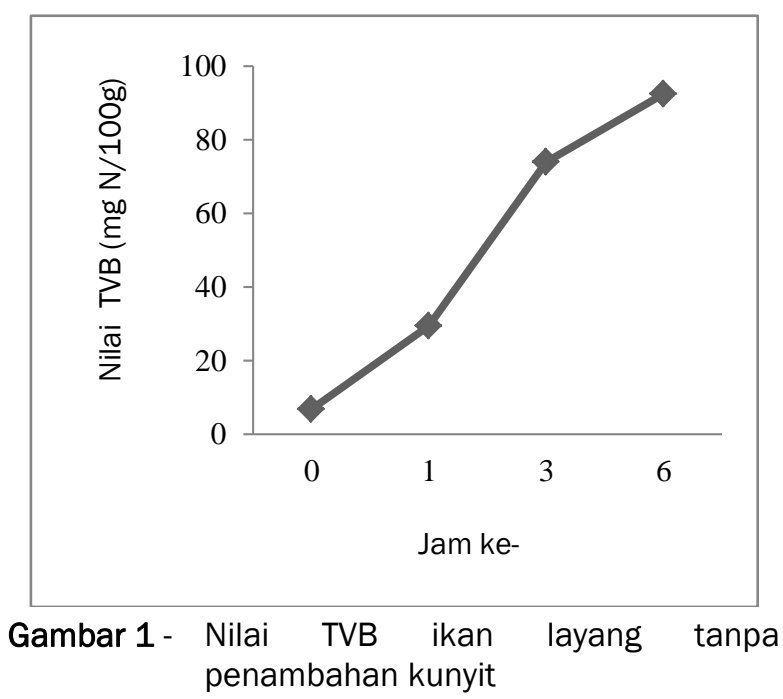

Gambar 1 menunjukkan bahwa ikan layang tanpa penambahan kunyit pada jam ke-0 memiliki nilai TVB 6,72 mg N/100 g dan pada jam berikutnya yaitu jam ke-1 adalah 29,4 mg N/100 g, jam ke-3 adalah 73,92 mg N/100 g, dan pada jam ke-6 adalah 92,4 mg N/100 g. Dari Gambar 1 terlihat 
bahwa nilai TVB meningkat dengan sangat cepat. Semakin tinggi nilai TVB maka semakin mundur tingkat kesegaran ikan (Suwetja, 1993). Ikan layang juga mempunyai tekstur yang lunak, jumlah protein yang tinggi sehingga menyebabkan terjadinya proses degradasi/deaminasi protein, peptida dan asam-asam amino yang terdapat dalam tubuh ikan layang oleh aktivitas bakteri yang menghasilkan senyawa-senyawa basa volatile antara lain amonia, dimetilamin, dan trimetilamin (Chairita, 2008). Faktor-faktor inilah yang menyebabkan ikan layang mengalami peningkatan jumlah TVB.

\subsection{Sampel Ikan layang dengan Penambahan $\mathbf{1 0 0}$ g Kunyit}

Nilai TVB ikan layang dengan penambahan 100 g kunyit dapat dilihat pada Gambar 2.

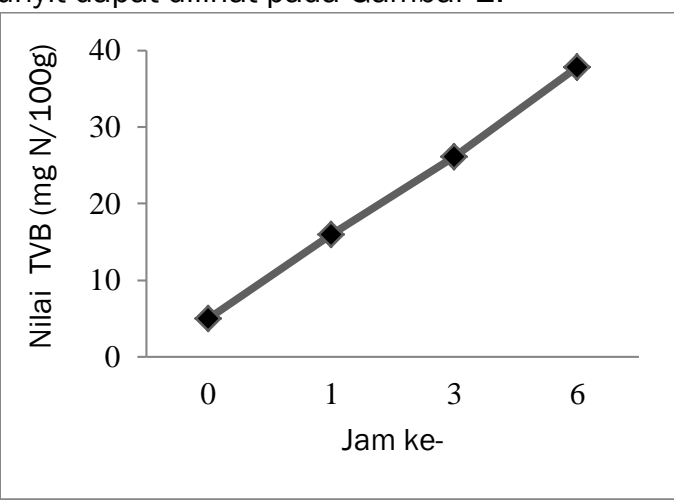

Gambar 2 - Nilai TVB ikan layang dengan perlakuan 100 g kunyit.

Gambar 2 menunjukkan nilai TVB untuk ikan yang diberi kunyit 100 g pada jam ke-0, ke-1, ke-3 dan ke-6 berturut-turut adalah 4,2 mg N/100 g, $5,88 \mathrm{mg} \mathrm{N} / 100 \mathrm{~g}, 22,68 \mathrm{mg} \mathrm{N} / 100 \mathrm{~g}$ dan 28,56 mg N/100 g. Ikan yang tidak di beri kunyit nilai TVB-nya lebih tinggi di bandingkan dengan ikan yang di beri kunyit $100 \mathrm{~g}$. Hal ini di sebabkan oleh zat-zat yang terkandung dalam kunyit yaitu minyak atsiri yang bersifat sebagai antibakteri. Golongan terpenoid adalah merupakan senyawa penyusun minyak atsiri golongan terpenoid yang memiliki aktivitas antibakteri adalah borneol, soneol, pinene, kamfene, kamjor, nerelidol dan kadinen (Pandiangan, 2008). Penelitian ini didukung oleh kesimpulan Marwati (1996). Senyawa-senyawa golongan terpenoid dapat merusak membran biologis sel atau asosiasi enzim sehingga pertumbuhan bakteri akan terhambat.

Selain minyak atsiri, kurkumin juga merupakan senyawa yang terdapat pada kunyit yang bersifat sebagai antibakteri. Kurkumin dalam rimpang kunyit merupakan kelompok persenyawan fenolik. Beberapa senyawa fenolik yang bersifat sebagai antimikroba adalah senyawa fenol, gingerol, zingeberen, halogen dan etiloksida (Pandiangan, 2008), Sebagai senyawa fenolik mekanisme kerja kurkumim sebagai antibakteri mirip dengan persenyawaan fenol lainnya yaitu menghambat metabolisme bakteri dengan cara merusak membran sitoplasma dan mendenaturasi protein sel yang menyebabkan kebocoran nutrien dari sel sehingga sel bakteri mati atau terhambat pertumbuhannya (Azima, 2011). Hal inilah yang menyebabkan ikan layang tidak di beri kunyit nilai TVB-nya lebih tinggi di banding dengan ikan layang dengan penambahan kunyit $100 \mathrm{~g}$.

\subsection{Sampel Ikan layang dengan Penambahan 200 g Kunyit}

Nilai TVB ikan layang dengan penambahan 200 g kunyit dapat dilihat pada Gambar 3.

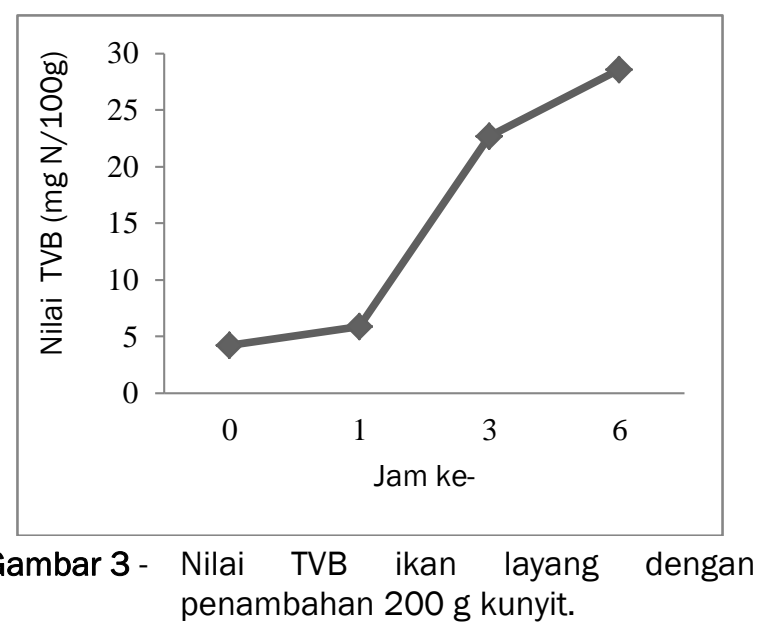

Gambar 3 menunjukkan nilai TVB ikan layang dengan penambahan 200 g kunyit pada jam ke-0, jam ke-1, ke-3 dan jam ke-6 berturut-turut adalah 4,2 mg N/100 g, 5,88 mg N/100 g, 22,68 mg $\mathrm{N} / 100 \mathrm{~g}$ dan 29,4 mg N/100 g. Ikan layang tanpa penambahan kunyit dan penambahan kunyit $100 \mathrm{~g}$, nilai TVB nya lebih tinggi dibandingkan dengan ikan yang diberi kunyit $200 \mathrm{~g}$. Hal ini artinya, semakin banyak penambahan kunyit pada sampel ikan layang, maka daya penghambat kurkumin dan minyak atsiri terhadap pertumbuhan bakteri semakin baik. Menurut Mawaddah (2008) kerja senyawa antimikroba adalah merusak dinding sel, mengubah permeabilitas membran sitoplasma sehingga menyebabkan terjadinya kebocoran nutrien dari dalam sel. Kerusakan dinding sel akan menyebabkan ganguan permeabilitas sel sehingga menyebabkan berkurangnya kemampuan sel dalam menjaga keutuhan struktur sel. Selain itu juga ganguan permeabilitas membran dapat menganggu kelangsungan metabolisme sel. Senyawa yang dapat mengganggu permeabilitas sel adalah fenol yang merupakan persenyawaan fenolik yang terdapat dalam kurkumin (Marwati, 1996). Kurkumin dan minyak atsiri merupakan zat-zat anti bakteri yang bersifat bakterisidal. Hal ini didukung oleh kesimpulan dari Fardiaz, 1992 bahwa zat antimikroba dapat bersifat bakterisidal (membunuh bakteri).

4. Kesimpulan
Rimpang tanaman kunyit dapat
mempertahankan mutu ikan layang karena
mengandung senyawa-senyawa kurkumin dan


minyak atsiri yang mempunyai kemampuan menghambat pertumbuhan bakteri. Hasil uji TVB menunjukan bahwa semakin tinggi konsentrasi kunyit maka nilai TVB ikan layang semakin rendah. Ini berarti bahwa daya penghambat kunyit terhadap pertumbuhan bakteri semakin baik.

\section{Daftar Pustaka}

Azima. 2011. Efektifitas Kunyit Sebagai Bahan Pengawet Alami Terhadap Masa Simpan Nugget Jagung. http://pasca.unand.ac.id/id/wpcontent/ uploads/2011/09/efektivitas-kunyit-sebagaipengawet-alami.pdf. [15Februari2013]

Berhimpon. 1982. Pengaruh Perendaman File (Fillet) Di Dalam Larutan Garam Dan Asam asetat Terhadap Kandungan Urea Dan Mutu Ikan Hiu (Carcharhins Limbatus) Selama Penyimpanan Beku. Fakultas Pasca Sarjana IPB Bogor.

Bengen, D. 2002. Pedoman Teknis Pengenalan ekosistem Mangrou. Pusat Kajian Pesisir dan Lautan. Institut Pertanian, Bogor.

Chairita, 2008. Karakteristik Bakso Ikan Dari Campuran Surimi Ikan Layang (Decapterus spp) Dan Ikan Kakap Merah (Latjanus sp) Pada Penyimpanan Suhu Dingin. http:// repository. ipb.ac.id/bitstrem/handle/123456789/9931/ CharlakarakteristikBaksolkan.pdf?sequene $=1$ [17 Oktober 2012]
Fardiaz, 1992. Analisis Mikrobiologi Pangan. Departemen Pangan dan Gizi, Institut Pertanian, Bogor.

Harisna, 2010. Pengaruh Ekstrak Kunyit (Curcuma domestica) Dengan Konsentrasi yang berbeda terhadap mikroba Pada Isolat Ikan Nila (Oreochromis niloticus). http://etd.Eprints.ums. ac.id/7637/1/J31005009. pdf [31Mei 2011]

Marwati, T. 1996. Aktivitas Zat Anti Bakteri Pada Rimpang Kunyit. http://www.Pustaka.Litbang.de ptan.go.id/bptpi/lengkap/IPTANA/fullteks/ApinM ap/ApMap5.pdf. [15 November 2012].

Mawaddah, R. 2008. Kajian Hasil Riset Potensi Antimikroba Alami Dan Aplikasinya Dalam Bahan Pangan di Pusat Informasi Teknologi Pertanian .Fateta Ipb. http://rep ositoryipb.ac.id/ bitstream/handle/ 1234 56789/1377 8/F08 sma.pdf ? sequence $=2$ [16 Februari 2013]

Pandiangan, 2008. Kajian Aktivitas Antimikroba Ekstrak Kunyit (Curcuma domestica Val) Terhadap Bakteri Patogen. http://isjd.pdii. lipi.go.id/admin/jun al/20720829930706521832.pdf [13 Oktober 2012].

Rahman, M. 2009. Aktivitas Anti Bakteri Senyawa Hasil Biotransformasi Kurkumin Oleh Mikrob Endofil Asal Kunyit. http://repository.ip b.ac.id/bitstream/handle/123456789/14837/ G09mnr.pdf [15 Februari 2013]

Suwetja. 1993. Metode Penentuan Mutu Ikan. Universitas Sam Ratulangi Fakultas Perikanan Manado. 